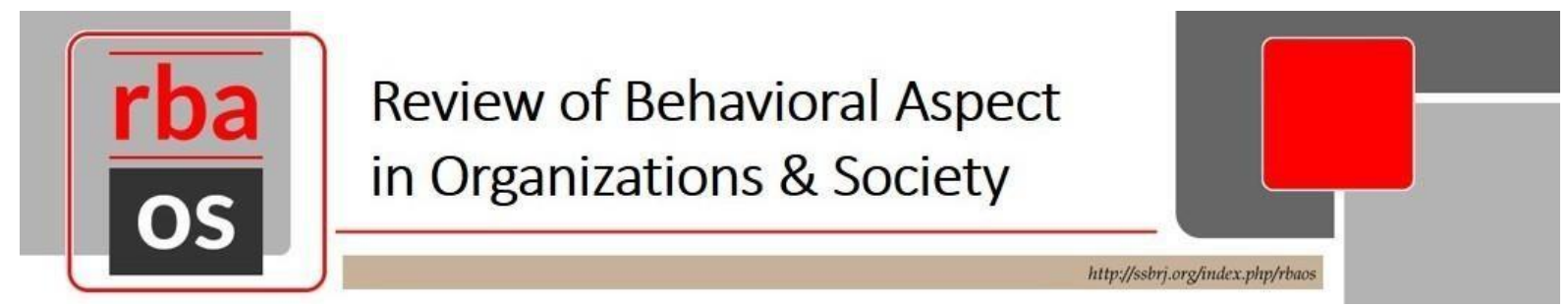

\title{
SOCIAL MEDIA CONTENT OF INSTAGRAM ON IMPULSE BUYING
}

\author{
Fitri Lestari, STIE Ekuitas, Indonesia
}

\begin{abstract}
Today technology is one of the most important business aspects as a facility that can give a company a competitive advantage by using social media. The high number of social media users makes the business producers use it as a promotion media. Bandung is a city center that offers all kinds of needs; one of them is fashion. The rapid development of fashion's creative industries is marked by the number of distribution outlets (distro), clothing, and factory outlets (FO) that increase from year to year. This research is conducted to determine the social media content of Instagram used by the Bandung fashion industries and its influence on impulse buying. The method used in this research is descriptive verification. The data collection technique is carried out through a questionnaire and interview. The respondents of this research are 100 consumers of 85 outlets. Based on the hypothesis testing using simple linear regression, it can be stated that the validity (significant) is "there is an influence of social media content of Instagram on impulse buying."
\end{abstract}

Keywords: social media content, impulse buying 


\section{Introduction}

The development of technology from time to time has created a digital era. This condition makes people addicted toward the technologies, one of them is internet. In this era the technology gets into its new level as a facility that can give a competitive profit to the companies especially business companies by using social media. According to the survey result of social media user data, Indonesia is on the sixth as the most social media user in the world. The users of social media in Indonesia reaches one hundred twenty-three million users. Bandung is the first city as the biggest social media users in West Java province with the total users 2.9 million of the total citizens. This condition is supported by the condition of the city itself which provides a lot of shopping places especially for clothing that attracts many tourists both local and international to come. This is evidenced by the rapid growth of the fashion creative industries in Bandung, such as the numbers of the distribution outlets, clothing and factory outlets which keep increasing from year to year. In business world today the changes and uncertainties really affect the company activities. The growth and the development of the existing companies creates a hard competition. This condition can be seen through the types of competition and the maintain its survival in accordance with its mission and objectives.

Unplanned buying behavior is something interesting for the company. The consumers as the decision makers mostly make unplanned purchasing immediately once when they are doing shopping in malls, supermarkets or stores. Impulsive buying is a process of purchasing a product where the buyer has no intention of buying before, the purchasing is made without a plan or spontaneously. (Suwarman in Wahyudi 2017:278).

An impulsive buying decision is made through the process of learning and thinking that finally create a perception emotionally. The impulsive buying decision is a decision that is influented by several factors that make the consumers purchase actually without considering or thinking rationally.

The company must keep creating the innovative and creative ideas in order to be able to compete with emerging companies. One of the strategies that can make the companies able to compete with is by using social media as a promotion tool to introduce their brands or products. One of the fast growing social medias is Instagram which is a social media with its goal to help the users to take pictures, use the digital filters and cut the pictures or videos and share them with other users.

\section{Literature Review}

Content Marketing

According to Gunelius in Mileva and friends. (2018), content marketing is a process of promoting a business or a brand directly or indirectly through a text content, video or audio that has a profitable value both online and offline. This process can be designed in a long form, such as blog, article, E-book, etc., a short form, such as twitter-update, Facebook-update, pictures, etc., or a conversation form, such as sharing contents on Instagram or participating in an active discussion via blog comments or online forums.

According to Handley A., in Mileva and friends, (2018), content marketing is something created by individuals or organizations to tell their stories like a conversation. Content marketing does not sell continuously and is not a tactic that can directly produce but must be a mindset that is embraced and encouraged. Karr (2016:9) states "companies are spending an inordinate amount of time crafting and promoting contents for prospects and customers. We often underestimate the cost of the content we are producing". It means that the company 
spends a lot of time to arrange, design and promote for the costumers. Therefore, the company often underestimates the expense for the content cost. There are five dimensions in creating a marketing content according to Karr (2016:9), they are,

1. Reader cognition

Reader cognition is a response from the customers regarding a content of the company whether the content is easy to understand including visual, audioable, and kinaesthetic interaction are needed to reach the customers.

2. Sharing motivation

Sharing motivation is a very important thing in a social field. There are some reasons why a company shares content, in addition to increasing the company's value, creating a corporate identity, as well as expanding the market network.

3. Persuasion

A content can attract the consumers to come and are persuaded to be customers.

4. Decision making

Every individual has a right to decide. Every decision is influenced by the trust toward the company, facts, and emotions arise

5. Factor

Other factors also influence the content presented, such as companies, friends, and families.

\section{Impulse Buying}

Impulse buying research is adapted from the buyer's decision because it has the same meaning, that is, spending Money to fulfil needs and desires. According to Solomon and Rabolt in Rofidi, N. (2017), impulse buying is a condition when an individual experiences a sudden urgency that can not be resisted. The tendency of spontaneous buying generally occurs when a buyer believes that his action is natural.

According to Rook and Fisher (1995), impulse buying is a tendency of consumers to buy spontaneously, reflectively, suddenly, and automatically. An impulsive buying occurs because there is a strong feeling urgency where the effective condition immediately creates the buyer's behaviour without forming trust and thinking hard to buy a product.

Based on some definitions above, it can be concluded that impulse buying is a condition when an individual experiences an urgent condition and makes a purchase spontaneously without any plan before.

According to Loudon and Bitta (2016:18), there are four dimensions in impulse buying, they are:

1. Pure impulse

Referring to an act of purchase for an interesting reason, a purchase usually occurs because of brand loyalty or buying behavior that is contrary to the normal type of purchase

2. Suggestion impulse

A buyer who has not had any knowledge of a product before sees the product for the first time and feels the need for that product.

3. Reminder impulse

A buyer sees a product and remembers that the stock of that product has been less, or remembers an advertisement or another information of a product and he has an advance decision.

4. Planned impulse 
Planning aspects in this behavior show the consumers' responds toward some special incentives to buy a product anticipatedly. This impulse is usually stimulated by the announcement of the coupon sell, coupon cut, or other interesting offers.

Impulse buying decision occurs mostly among people mainly those who live in big cities. The impulsive buying behavior can be caused by many aspects, such as interesting product, promotion like giving discount, advertisement, or a reminder to consumers for fulfilling their main needs when they see a product displayed.

\section{The Relationship of Content Marketing and Impulse Buying}

Content marketing is a marketing promotion activity that is an invitation to give incentive to buy a product. It is consumer oriented that causes the consumer has a buying motive that is seen as an arising need, stimulation, or desire. This motive acts as a force that stimulates behavior that can lead to decision making, one of which is emotional. According to Cummin in Mullin and friends (2015), content marketing has a goal to motivate consumers to buy, it means there is a consumer's behavor in buying activity that involves emotion for the buyer. This arises because of the attraction of certain sentiment or passion, and this condition occurs because of the urge to meet the needs of life quickly. David S., in Mullin and friends (2015) states that the purpose of the content marketing is to increase the sales volume by creating attractive displays and activities to encourage impulsive buying. This display causes an excitement to buy or is a stimulus of behavior to satisfy the life necessities.

\section{Methodology}

The analysis used in this study is descriptive verificative. Descriptive analysis is an analysis used to describe the tourists' perseptions about the content in social media and impulse buying. Verificative analysis is a regression analysis used to find out how high the influence of social media content on impulse buying.

The object of this research is clothing outlets in Bandung, with the criteria of promotion tool used is social media. From the total 240 of clothing outlets, 85 of them use social media of Instagram as a promotion tool with the total buyers 415.315 people, and with the number of sample is 100 people. The technique used is sampling proportion according to the number of buyers and followers from each outlet. The dimensions used from the content variables of social media of Instagram are; reader cognition, sharing motivation, persuasion, decision making, and factors, while the dimensions from impulse buying are; pure impulse, suggestion impulse, reminder impulse, and planned impulse. The result of data processing from that dimension for simple linear regression can be interpreted that as an independent variable, the social media content of Instagram (X) has a positive effect with value toward dependent variable of impulse buying (Y). But there are some indicators have low value or less good. 


\section{Results and Discussion}

Descriptive analysis

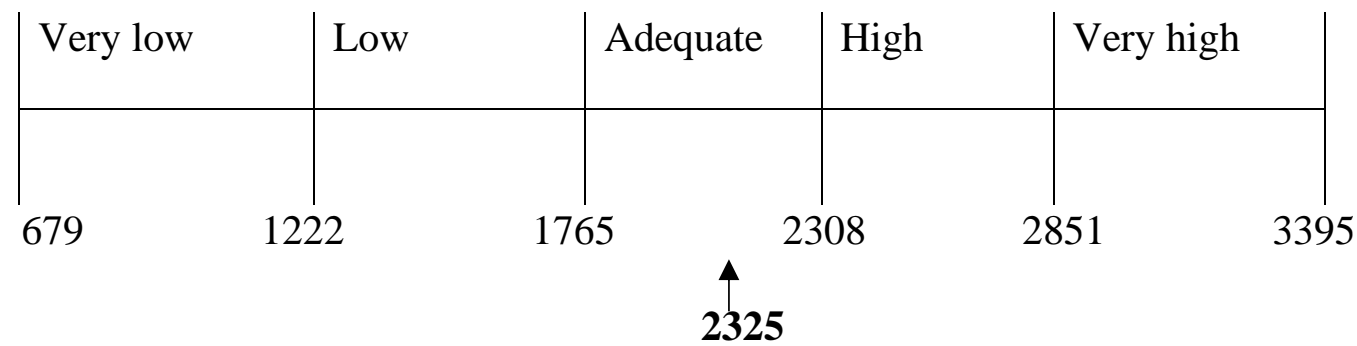

Figure 1. Variable Continuum Lines of Social Media Content

Based on the continuum line above it shows that the total score of social media content variable is 2325 , while the ideal score is 3395 . So the variable content of social media is on the high category in involving impulse buying. Based on seven statements of social media content variable, the statement that has the highest score with the indicator of product purchasing desire just by seeing the testimony, the respondents consider that the information from buyers' testimonies with positive responses make other buyers interested to buy the clothing products. This condition is accordance with the theory. According Huang in Puspitasari, and friends, (2017) "the good marketing content can make the costumers interested in the product page by affecting their attitudes and interests". The same result of the research that attitudes towards pop-ups / advertisements have a strong positive correlation in an informative and entertaining way was stated by Amy, Y. C. M., Carter, S., \& Shuo, K. Z. (2019). Positive testimonials are advertising content that contains information that can provide an influence or invitation to buy clothing or outlets. According to Katuwandeniya, I. M., \& Abeywardana, A. R. S. (2019) Further analyses revealed that 'factors in communicating', 'Influencers recommendations', 'opinion leaders advice' and 'agreements with reference partner' making a unique contribution of prediction to the decision-making process. It indicates the reasons why this group of millennials prefers to go to their reference partners. Some of which could be that they need them for expert advice that enables them to make the correct decision based on their experience, know the best deal and where to get the products.

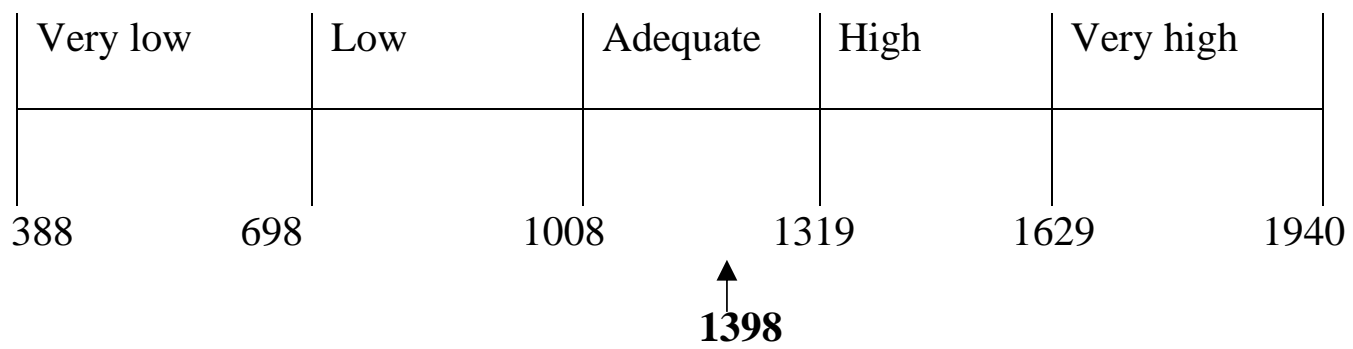

Figure 2. Continuum Line of Impulse Buying Variable

Based on Figure 2 above the continuum line shows that the total score of impulse buying variable is 1398 and the ideal score is 1940 . So the impulse buying is on the category of adequate. From seven statements of impulse buying, the statement that has the highest score is that the consumers will consider the decision of product purchasing because of coupon or promo offer. This condition is accordance with the Solomon and Rabolt theory in Rafidi, N. (2017) that says "impulsive purchase happens when the customer has a sudden urgency that can not be resisted. The tendency to purchase the product this way generally can result a purchase. Nowdays the attitude of consumers can be called in an urgency when they can not 
resist the desires because of some aspects such as good quality of clothing products, and cheap or interesting products.

Regression Analysis

Table 1. Result of the Simple Linear Regression

\begin{tabular}{|c|c|c|c|c|c|c|}
\hline \multirow{2}{*}{\multicolumn{2}{|c|}{ Model }} & \multicolumn{2}{|c|}{$\begin{array}{c}\text { Unstandardized } \\
\text { Coefficients }\end{array}$} & \multirow{2}{*}{$\begin{array}{c}\begin{array}{c}\text { Standardized } \\
\text { Coefficients }\end{array} \\
\text { Beta }\end{array}$} & \multirow[b]{2}{*}{$\mathrm{t}$} & \multirow[b]{2}{*}{ Sig. } \\
\hline & & $\mathrm{B}$ & Std. Error & & & \\
\hline \multirow[t]{2}{*}{1} & (Constant) & 7.429 & 1.173 & & 6.331 & 0.000 \\
\hline & Social Media & 0.290 & 0.048 & 0.524 & 5.995 & 0.000 \\
\hline
\end{tabular}

a. Dependent Variable: impulse buying

Based on Table 1, the regression equation gained is:

$$
\mathrm{Y}=7.429+0.290 \mathrm{X}
$$

The equation above shows that social media has an effect on impulse buying: 0.290 or $2.9 \%$. The constant of 7.429 shows that if there are no social media, the impulse buying is 7.429. the regression coefficient of 2.90 shows that each addition (because of the sign of + ) 1 social media will increase impulse buying of 0.290 .

\section{F Test (Simultaneous)}

F test or coefficient is sed to determine whether social media affects impulse buying or not and vise versa.

Table 2. ANOVA Output

\begin{tabular}{llccccc}
\hline \multirow{2}{*}{ Model } & $\begin{array}{c}\text { Sum of } \\
\text { Squares }\end{array}$ & df & Mean Square & F & Sig. \\
\hline 1 & Regression & 4638.961 & 2 & 4638.961 & 89.605 & $0.000^{\mathrm{a}}$ \\
& Residual & 5073.559 & 97 & 51.771 & & \\
Total & 9712.520 & 99 & & & \\
\hline
\end{tabular}

a. Predictors: (Constant), Social Media

b. Dependent Variable: Impulse Buying

Source: Data Processing Result 2020

Based on Table 2 above, the results of the social media $F$ test on impulse buying are:

1. The $\mathrm{F}$ arithmetic means is 89.605 then compared with $\mathrm{F}$ table $(\mathrm{k}: \mathrm{n}-\mathrm{k})$. As known that the total respondents is $100(n=100)$. So it gains F table $(2: 100-2)$ is 2.04 . so it is known that the F arithmetic means $(89,605 \geq 2,04)$. So H0 is resisted and $\mathrm{H} 1$ is accepted.

2. The F test's significance score is 0.000 and smaller than the significance level of $5 \%$ $(0,000<0.05)$, so H0 is resisted accepted.

The t-test (partial)

The t-test is the partial hypothesis test to find out the role of social media in affecting impulse buying. 
Table 3. t-test Results

\begin{tabular}{|c|c|c|c|c|c|c|}
\hline \multirow{2}{*}{\multicolumn{2}{|c|}{ Model }} & \multicolumn{2}{|c|}{$\begin{array}{c}\text { Unstandardized } \\
\text { Coefficients }\end{array}$} & \multicolumn{3}{|c|}{$\begin{array}{l}\text { Standardized } \\
\text { Coefficients }\end{array}$} \\
\hline & & $\mathrm{B}$ & Std. Error & Beta & $\mathrm{t}$ & Sig. \\
\hline \multirow[t]{2}{*}{1} & (Constant) & 7.429 & 1.173 & & 6.331 & 0.000 \\
\hline & Social Media & 0.290 & 0.048 & 0.524 & 5.995 & 0.000 \\
\hline
\end{tabular}

a. Dependent Variable: impulse buying

Based on Table 3, the result of the hypothesis test is that the $t$ arithmetic means of 5.995 then compared with t table $=1.66$, so it can be found out that the $t$ arithmetic means is $(5,995 \geq$ 1,66). So $\mathrm{H} 0$ is resisted and $\mathrm{H} 1$ is accepted. It means the social media variable has a positive impact on impulse buying.

\section{Conclusion}

Social media has an impact of $2.9 \%$ on impulse buying. Several strategy content programs can increase the sale, such as updating the new goods regularly by adding pictures and videos, hiring a phenomenal Instagram celebrity who has many followers, using discount caption based on the chosen topic, and giving discounts to those who are having a birthday on that date. The posts made are not always about selling products but also about some information for sharing or motivations that can support the followers, so that the followers will always keep following all posts of the clothing store or the factory outlet.

\section{References}

Amy, Y. C. M., Carter, S., \& Shuo, K. Z. (2019). Leadership, contribution, language and shared content as metrics in Malaysian millennials'decision making. Journal of Business and Finance in Emerging Markets, 2(2), 153-162.

Karr, D. (2016). How to Map Your Content to Unpredictable Customer Journeys. San Francisco: Meltwater.

Katuwandeniya, I. M., \& Abeywardana, A. R. S. (2019). Web users'attitude toward pop-up advertisements in Western province of Sri Lanka. Review of Behavioral Aspect in Organizations and Society, 1(2), 149-158.

Loudon, D.L., and Bitta, A.J.D. (2016). Consumer Behavior: Concepts and Applications. New York: McGraw-Hill.

Mileva, L., \& Fauzi, A. (2018). The effect of social media marketing on purchasing decisions. (Online survey of bachelor of Business Administration Department 2014/2015 bachelors of Business Administration Faculty of Brawijaya University who buy Starbucks using line). Business administration journal,58(1), 190-199.

Puspitasari, P., Tresnati, R., \& Oktini, R. (2017). The influence of content marketing on buying interest. (The survey on customers of thirteenth shoes Bandung). Prosiding manajemen, 3(1), 2460-6545

Rofidi, N. (2017). The influence of discount price, pack bonus and service on the increase of impulse buying on the store of UD Aryan at sub-district of Plemahan, district of Kediri (translated from Indonesia: Pengaruh price discount, bonus pack dan pelayanan terhadap peningkatan impulse buying pada toko bangunan UD. Aryan kecamatan Plemahan kabupaten Kediri). Simki-Economic, 1(3), 2-16.

Rook, D. W., \& Fisher, R. J. (1995). Normative influences on impulsive buying behavior. Journal of consumer research, 22(3), 305-313. 
Wahyudi, S. (2017). The influence of Discount Price on Impulse Buying (translated from Indonesia: Pengaruh Pprice discount terhadap impulse buying). Jurnal valuta, 3(2), 276-289.

Gomies, S. J., Tamalene, A. H., \& Pattipeilohy, V. R. (2018). The effect of money availability and hedonic consumption on impulse buying of souvenirs from Ambon City (translated from Indonesia: Pengaruh ketersediaan uang dan konsumsi hedonis terhadap pembelian impulse produk ole-ole khas Kota Ambon). Jurnal maneksi, 7(2), 94-99. 